\section{THE GAS INDUSTRY IN GREAT BRITAIN AFTER THE WAR}

7 r

HE Institution of Gas Engineers held its seventyninth annual meeting in London on June 10, under the presidency of Sir Frederick J. West, of Manchester. The main business was the discussion of six short papers dealing with the place of the gas industry in meeting the post-war needs of Great Britain. Throughout the papers ran an emphasis on the need for greater and more thorough education of the personnel of the industry under the conditions of the future. Prof. D. T. A. Townend reviewed the development of university education since the industry applied the Livesey Fund in 1910 to endow a chair in coal gas and fuel industries in the University of Leeds. Recently the University has extended and widened the curriculum by incorporating courses in chemical engineering.

Mr. E. V. Evans, of London, vice-president, gave an account of the progress and intentions of the Gas Research Board established shortly before the outbreak of war. The gas industry of Great Britain can claim a long and effective experience in sponsoring co-operative investigations for the common good, but on a scale which was long felt to be inadequate to meet present and future needs. The new Board was devised to provide for great and necessary developments, but for obvious reasons these have been hindered by the War. Much of what has been done is of a nature which precludes publication.

To-day the most important technical question before the gas industry is the choice between carbonization and complete gasification of coal. In the future, will coal be carbonized in retorts to yield both gas and coke, or will the main product be gas only and no coke? The possibility of complete gasification of coal under pressure has been shown to be technically possible, but it remains to be shown to be commercially feasible. Success is of great national importance. The industry would be free to use almost any class of coal, free to control the amount of coke produced, and independent of imported mineral oil for the enrichment of water gas. The War has delayed the search for the answer to this problem, and much depends on the answer.

If it is shown possible to convert coal into a suitable gas without coke residue and at an acceptable price, then consumers might reach the fortunate position of those in countries with supplies of natural gas. If this quest is unsuccessful, then the industry must organize itself to supply a combination of gas and coke. The industry has already gone far to inform itself of the size of the problem. In London it has been shown from fuel bills that householders of low purchasing power need 274 therms of 'useful' heat, that is, gross heat in fuel consumed with a correction for efficiency of utilization. Mr. E. Crowther, of Newcastle, in a paper advocating the use of gas for supplying all the heat needs of householders, recorded experience with many houses specially designed and equipped for the purpose. Fuel bills show that in Newcastle the corresponding figure is 316 'useful' therms. With the tariff charges applied the total costs were of the same order as those found when the dwellings were heated by older methods.

Dr. Harold Hartley, of Birmingham, voiced the views of those who envisage the joint use of gas and coke. At present, gas is used in some measure by the great majority of householders, primarily for cooking. For space-heating its use is mainly for intermittent needs, and the bulk is supplied by solid fuels, coke yielding the cheapest service. If, however, gas were available on a two-part tariff comparable with that in the telephone service, then a very large increase in the use of gas for space-heating could be expected. For water-heating the present growth of consumption of coke will continue. It is believed that 60 per cent of domestic fuel used in Great Britain is bituminous coal, and the use of much coal is likely to continue for many years. Unless means for burning coal smokelessly can be devised, the only hope for the abatement of domestic smoke will depend on the extension of the production of gas and coke by carbonization. While there will always be some who can and will satisfy all the needs for domestic heat by electricity, Dr. Hartley thinks there will be only a limited development of the 'all electric' house. To-day the coal industry ranks first as the source of domestic heat supplies in Great Britain, but he believes that, given a suitable system of charging, the gas industry would in our lifetime attain the leading position.

The two other papers concerned more technical matters. Mr. T. C. Finlayson, of London, discussed methods for promoting efficiency and, therefore, fuelsaving in the production of gas. Dr. E. A. C. Chamberlain dealt with the same problem as it appears in the use of gas in industry-to-day enormously increased by war conditions. Gaseous fuels in furnaces offer great conveniences and possibility of fuel-saving in furnaces. This very ease of use and effortless control, however, offers a temptation to effortless and unnecessary consumption. His paper dealt with the potontial savings by scientific control.

\section{SHOOT ORGANIZATION IN DICOTYLEDON AND MONO- COTYLEDON}

\begin{abstract}
$A$
PAPER by C. P. Majumdar (Ann. Bot., 6, No. 21 , January, 1942) on the organization of the shoot of Heracleum Sphondylium leads to an interesting comparison of the mode of growth of the dicotyledon and the monocotyledon. One distinction frequently made between the two is that the leaf has a com. paratively narrow insertion in the dicotyledon, and as a result room is found for two cotyledons around the embryonic apex; in the monocotyledon the leaf insertion is wide, often completely encircling the axis, and there is only one cotyledon. Two families of Dicotyledons, the Ranunculaceæ and Umbelliferæ, are characterized by unusually wide leaf insertions, and it is suggestive that all the best authenticated cases of monocotylous dicotyledons have been reported from these families.

Majumdar's examination of the development of the vegetative shoot of Heracleum directs particular attention to the effect of this wide leaf insertion upon the development and anatomy of the shoot, and once more to the remarkable 'leaf cushions' and 'bud cushions' which are one characteristic result of this feature of the umbellifer shoot. But more general interest, perhaps, is attached to the interesting analysis of the axial structure in this type, which, in spite of the multi-lacunar leaf-gap, due to the large number of trace strands entering the axis from the one wide.
\end{abstract}

